\title{
Indoor nitrogen dioxide in homes along trunk roads with heavy traffic
}

\author{
Masayuki Shima, Motoaki Adachi
}

\begin{abstract}
Objectives-To assess the distribution of indoor nitrogen dioxide $\left(\mathrm{NO}_{2}\right)$ concentrations in homes located in differing environments, and to investigate the influence of factors such as automobile exhaust on the indoor environment.

Methods-The concentrations of indoor $\mathrm{NO}_{2}$ over 24 hours were measured in both the heating and non-heating periods in homes of pupils from nine elementary schools in Chiba, Japan. Information on factors that could influence indoor environments was collected by questionnaire. Results-Indoor $\mathrm{NO}_{2}$ concentrations during the heating period were higher in homes with unvented heaters than in homes with vented heaters, although the concentrations varied greatly among homes primarily because of the type of heating device used. During the nonheating period, indoor $\mathrm{NO}_{2}$ concentrations were significantly higher in homes adjacent to trunk roads than in homes located in other areas. Multiple regression analysis showed that indoor $\mathrm{NO}_{2}$ concentrations were associated with atmospheric $\mathrm{NO}_{2}$ in homes with vented heaters during the heating period, and in homes in areas other than on the roadside during the non-heating period. In areas other than the roadside, cigarette smoking in indoor environments also significantly contributed to indoor $\mathrm{NO}_{2}$. The average concentrations of indoor $\mathrm{NO}_{2}$ in the homes of pupils attending each school were significantly related to the atmospheric $\mathrm{NO}_{2}$ in areas other than the roadside. However, the relation between indoor and atmospheric $\mathrm{NO}_{2}$ concentrations was not significant in roadside areas.
\end{abstract}

Conclusions-These findings suggest that indoor $\mathrm{NO}_{2}$ concentrations are related to the atmospheric $\mathrm{NO}_{2}$ and type of heating appliances, and are also affected by automobile exhaust in homes located in roadside areas.

(Occup Environ Med 1998;55:428-433)

Keywords: nitrogen dioxide; air pollution; indoor environment

Correspondence to: Dr Masayuki Shima, Department of Public Health, Chiba University School of Medicine, 1-8-1 Inohana, Chuo-ku, Chiba 260-8670, Japan. Tel: 0081 43226 2068; Fax: 008143 226 2070; Email:

sima@med.m.chiba-u.ac.jp

Accepted 27 November 1997 main pollutants in automobile exhaust, and the atmospheric concentration of $\mathrm{NO}_{2}$ is higher in
Recently, increasing automobile traffic in Japan has caused considerably higher levels of air pollution derived primarily from automobile areas adjacent to major trunk roads with heavy traffic than in the general environment. ${ }^{23}$ The potential effect of $\mathrm{NO}_{2}$ on the health of residents who live near trunk roads is a matter of concern. ${ }^{4-6}$

Nitrogen dioxide is also produced by the use of combustion appliances in homes, ${ }^{7}$ and its concentration may exceed that outdoors in homes with unvented heating appliances. ${ }^{7}$ Therefore, in evaluating the effects of automobile exhaust on human health, additional indoor environmental effects-such as the use of heating appliances - should be considered. ${ }^{9-11}$ Several studies have assessed the indoor or personal exposure concentrations of $\mathrm{NO}_{2}$ in homes adjacent to trunk roads, as a risk factor for respiratory health. ${ }^{23}$ Because of methodological problems and inadequate sample size, however, these studies have not sufficiently elucidated levels of indoor air pollution.

To evaluate the effects of various environmental factors on respiratory health, we have been conducting a series of epidemiological surveys in school children. ${ }^{12}{ }^{13}$ In this study, we measured indoor $\mathrm{NO}_{2}$ concentrations in the homes of school children living in areas that contain major trunk roads. We investigated the relations between these measurements and indoor environmental factors such as type of heating appliances used, atmospheric levels of air pollution, and distance of the home from the trunk road.

\section{Materials and methods}

SUBJECTS

The subjects of this study were 1029 fourth grade pupils (aged 9-10 years) attending nine elementary schools in various regions of Chiba Prefecture, Japan. Of these schools, six are located in urban areas, and their school districts are intersected by major trunk roads that are all national highways or motorways. The daytime average traffic densities of these roads ranged from about 17000 to 82000 vehicles every 12 hours in 1990; heavy vehicles accounted for $26.8 \%$ of the traffic at that time. One of the remaining three schools was located in a suburban area, and the other two schools were in rural areas. In each of these cases, there were no major roads within the school district.

The annual average concentrations of $\mathrm{NO}_{2}$ in 1993, measured by Saltzman's method, ${ }^{14}$ at ambient air monitoring stations in the vicinities of these schools, were 26-32 ppb for urban areas, $20 \mathrm{ppb}$ for suburban areas, and 7-11 ppb for rural areas. The greatest distance between a school and the monitoring station was $3 \mathrm{~km}$ for one rural school, whereas the distances were $0-1.2 \mathrm{~km}$ for the other eight schools. In January and June 1991, we measured the 24 hour 
Table 1 Number of homes with available measurement of indoor $\mathrm{NO}_{2}$, by area, period, and type of heaters used in winter

\begin{tabular}{|c|c|c|c|c|c|}
\hline \multirow[b]{2}{*}{ District } & \multirow[b]{2}{*}{$\begin{array}{l}\text { Initial } \\
\text { subjects }\end{array}$} & \multicolumn{3}{|l|}{ Heating period } & \multirow[b]{2}{*}{$\begin{array}{l}\text { Non-heating } \\
\text { period }(n(\%))\end{array}$} \\
\hline & & $\begin{array}{l}\text { Homes with unvented } \\
\text { heaters }\end{array}$ & $\begin{array}{l}\text { Homes with vented } \\
\text { heaters }\end{array}$ & Total (n (\%)) & \\
\hline \multicolumn{6}{|l|}{ Urban areas: } \\
\hline $0-49 \mathrm{~m}$ from major roads & 94 & 49 & 34 & $83(88.3)$ & $77(81.9)$ \\
\hline$\geqslant 50 \mathrm{~m}$ from major roads & 543 & 307 & 192 & $499(91.9)$ & $472(86.9)$ \\
\hline Suburban area & 130 & 99 & 26 & $125(96.2)$ & $120(92.3)$ \\
\hline Rural areas & 262 & 185 & 58 & $243(92.7)$ & $236(90.1)$ \\
\hline Total & 1029 & 640 & 310 & $950(92.3)$ & $905(87.9)$ \\
\hline
\end{tabular}

average outdoor $\mathrm{NO}_{2}$ with badge type samplers (Toyo Roshi, Tokyo, Japan) at several points surrounding these schools. ${ }^{15}{ }^{16}$ In each case, the differences between their concentrations and the $\mathrm{NO}_{2}$ concentrations obtained on the days at the monitoring station near the school were within $\pm 10 \%$.

MEASUREMENTS OF INDOOR $\mathrm{NO}_{2}$ CONCENTRATIONS

In October 1992, a standard respiratory symptom questionnaire, the modified Japanese version of ATS-DLD-78-C, ${ }^{17}$ was sent to all the subjects. It was completed by either their parents or guardians. The questionnaire covered the respiratory symptoms of the children, the structure of the house and window frames, and the indoor environments of the home. Measurements of indoor $\mathrm{NO}_{2}$ concentrations were carried out in each subject's home on two occasions, in January or February 1993 (heating period) and in June or July 1993 (nonheating period), by which time the subjects had become fifth grade pupils. Indoor $\mathrm{NO}_{2}$ concentrations were measured with badge type
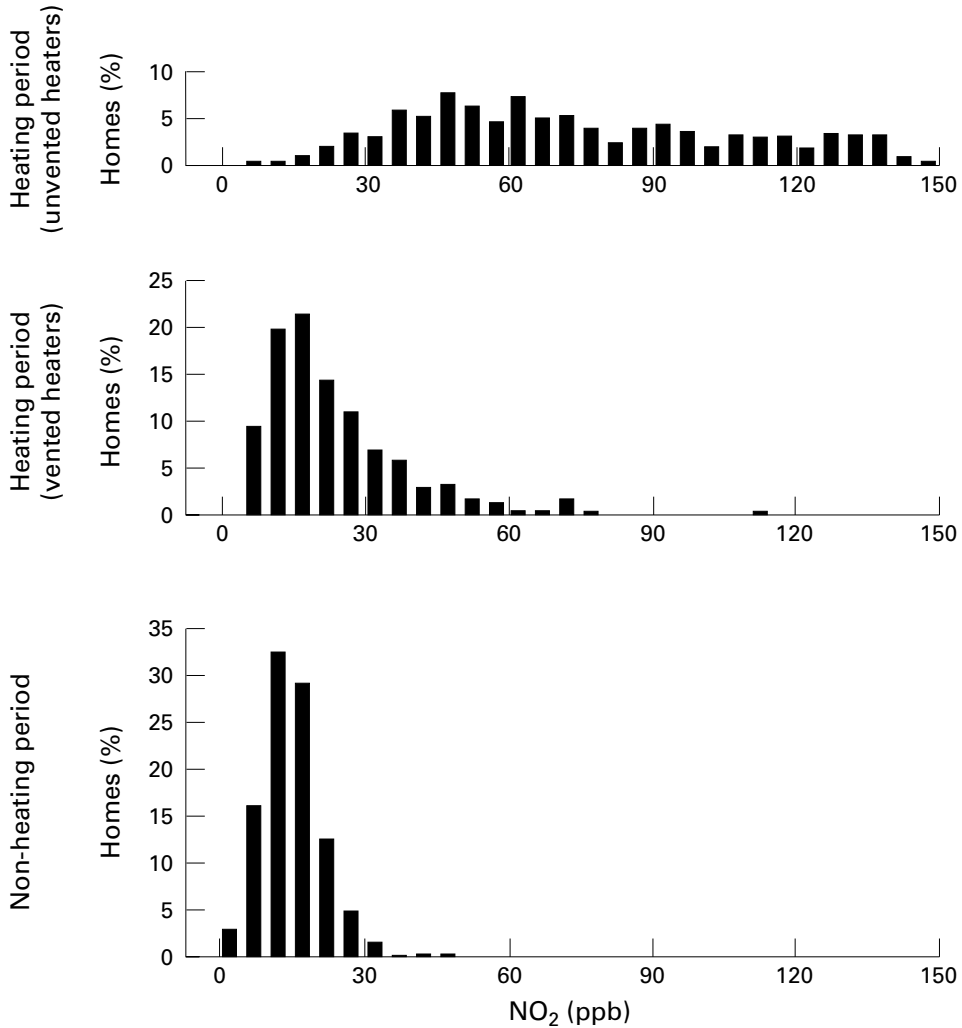

Figure 1 Distribution of indoor $\mathrm{NO}_{2}$ concentrations by period and type of heaters used in winter. samplers. ${ }^{15}$ Badges were distributed along with booklets, after a detailed verbal explanation for use at the schools. The subjects were instructed to take them home, break the seal, and place them on top of the television set in the living room. After the badges had been left for 24 hours, they were sealed in aluminium packs and collected. The badges, including blanks, were analysed spectrophotometrically, and the 24 hour average concentrations of $\mathrm{NO}_{2}(\mathrm{ppb})$ were recorded. The sensitivity of the badge is $66 \mathrm{ppb}$ per hour, and the accuracy is within $\pm 20 \%{ }^{15}$

The measurement time, the number of cigarettes that were smoked by the household members in the room during the measurement period, and the use and type of heating appliances (during the heating period only) were ascertained by questionnaire. The subjects were asked to identify their heating appliance from among five types, and the presence or absence of an exhaust outlet was confirmed with illustrations of various shaped outlets.

\section{DATA ANALYSIS}

For pupils from the six urban schools, the distance between their homes and the trunk roads was measured on maps. The subjects were then classified into two groups: homes $<50 \mathrm{~m}$ from the edge of trunk roads (roadside area) and those $\geqslant 50 \mathrm{~m}$ from the roads (non-roadside area). Indoor $\mathrm{NO}_{2}$ concentrations in each period were compared for the four areas: roadside, non-roadside, suburban, and rural. Significance was evaluated by analysis of variance (ANOVA), followed by Turkey's method. Comparisons relative to the other factors were conducted by Student's $t$ test.

The influences of the various factors were evaluated with multiple regression models with indoor $\mathrm{NO}_{2}$ concentrations as the dependent variable. The atmospheric $\mathrm{NO}_{2}$ concentrations, whether one cigarette or more were smoked in the room during the measurement period, the structure of the house, and the type of window frames were included in the models as independent variables. The 24 hour average of $\mathrm{NO}_{2}$ concentrations obtained on the day of our measurements at the monitoring station near each school were used as the atmospheric $\mathrm{NO}_{2}$ concentrations. These analyses were conducted separately for the measurement period, the type of heaters (during the heating period only), and the distance from trunk roads. Moreover, we calculated the average concentration of $\mathrm{NO}_{2}$ in the homes of pupils in each school in each period, and evaluated the correlation with the atmospheric $\mathrm{NO}_{2}$ concentrations. For urban 


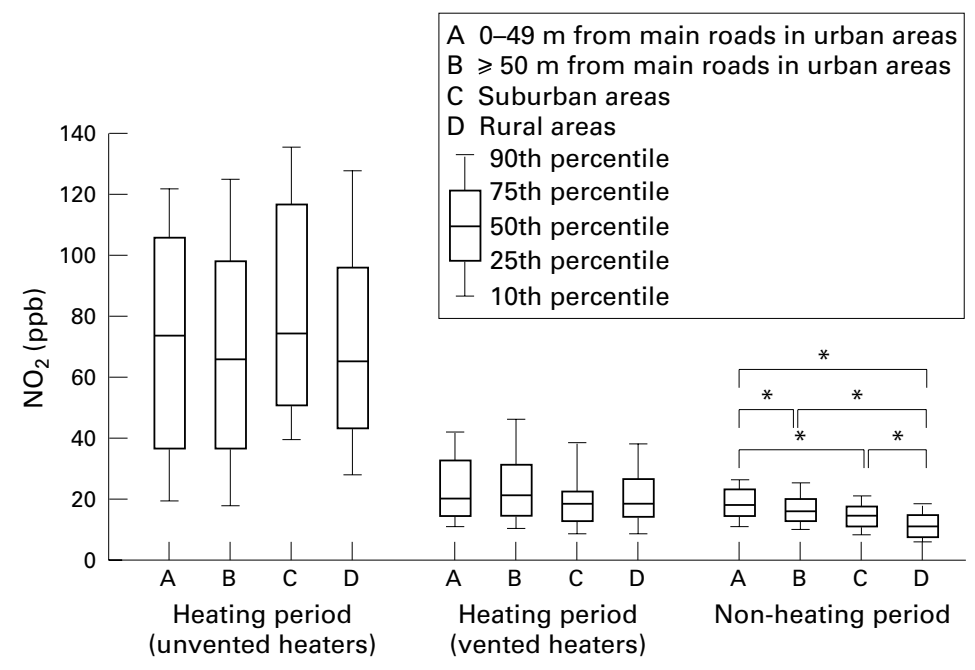

Figure 2 Distribution of indoor $\mathrm{NO}_{2}$ concentrations by location of homes, period, and type of heaters used in winter. ${ }^{\star} p<0.01$.

schools, the concentrations were calculated for the roadside and non-roadside homes, respectively.

\section{Results}

NUMBER OF SUBJECTS AND DISTRIBUTION OF INDOOR $\mathrm{NO}_{2}$ CONCENTRATIONS

The badges were collected from 1022 homes $(99.3 \%)$ for the heating period, and 1006 homes $(97.8 \%)$ for the non-heating period. In 22 of these homes for both periods, information on the structure of the house and window frames was not complete. Homes in which the measurement time was unclear, 22 hours or less, or 26 hours or more, were excluded (heating period, 50 homes; non-heating period, 79 homes). Thus, the final sample for analysis comprised 950 homes for the heating period and 905 for the non-heating period. During the heating period, 640 homes used unvented heaters, and 310 homes used vented heaters (table 1).

The indoor $\mathrm{NO}_{2}$ concentrations by period and type of heaters showed a skewed distribution (fig 1). The geometric mean in the heating period was higher in homes with unvented heaters (geometric mean: $66.4 \mathrm{ppb}$, range: 5-172 $\mathrm{ppb})$ than in homes with vented heaters (20.6 ppb, 6-112 ppb). In the non-heating period, the geometric mean of indoor $\mathrm{NO}_{2}$ concentrations was lower $(13.8 \mathrm{ppb})$ than in the heating period, and the range was smaller (2-47 ppb).
INDOOR $\mathrm{NO}_{2}$ CONCENTRATIONS BY AREA

Figure 2 shows the distributions of indoor $\mathrm{NO}_{2}$ concentrations by area and period. The medians in homes with unvented heaters during the heating period were $73 \mathrm{ppb}$ for the roadside area, $66 \mathrm{ppb}$ for the non-roadside area, $73 \mathrm{ppb}$ for the suburban area, and $64 \mathrm{ppb}$ for the rural area. The values in homes with vented heaters were $20,21,19$, and $19 \mathrm{ppb}$, respectively, and were lower than in homes with unvented heaters. The differences among the four areas were not significant in homes with unvented or vented heaters. The medians of indoor $\mathrm{NO}_{2}$ concentrations during the non-heating period were $18,16,15$, and $11 \mathrm{ppb}$, respectively. The value was significantly lower in the rural area than in the other areas. The value in the roadside area was significantly higher than in the non-roadside and suburban areas, whereas the difference between the non-roadside and suburban areas was not significant.

Table 2 shows the indoor $\mathrm{NO}_{2}$ concentrations relative to smoking in the room, structure of the house, and type of window frames. Cigarette smoking in indoor environments significantly increased the indoor $\mathrm{NO}_{2}$ concentrations during the non-heating period. The effect of indoor smoking was also shown in homes with unvented heaters during the heating period, although such an effect was not found in homes with vented heaters. The indoor $\mathrm{NO}_{2}$ concentrations during the non-heating period were significantly higher in steel or reinforced concrete houses than in wooden houses. During the heating period, however, there were no differences relative to the structure of the house, in both homes with unvented and vented heaters. In the houses with unvented heaters during both the heating and the non-heating period, the indoor $\mathrm{NO}_{2}$ concentrations were significantly higher in houses with aluminum window frames than in those with wooden windows. However, no significant difference due to the type of window frames was detected in homes with vented heaters during the heating period.

MULTIVARIATE ANALYSIS OF INDOOR $\mathrm{NO}_{2}$ CONCENTRATIONS

The multiple regression analyses of various factors on the indoor $\mathrm{NO}_{2}$ concentrations were conducted separately for the measurement period, the type of heaters, and the distance from trunk roads (table 3). In homes with unvented heaters during the heating period, no factor significantly contributed to indoor $\mathrm{NO}_{2}$ in

Table 2 Mean concentrations (ppb) of indoor $\mathrm{NO}_{2}$ in relation to smoking in the home, structure of the house, and type of window frames

\begin{tabular}{|c|c|c|c|c|c|c|c|c|c|}
\hline & \multicolumn{6}{|c|}{ Heating period } & & & \\
\hline & \multicolumn{3}{|c|}{ Homes with unvented heaters } & \multicolumn{3}{|c|}{ Homes with vented heaters } & \multicolumn{3}{|c|}{ Non-heating period } \\
\hline & $\bar{n}$ & Mean (SEM) & $p$ Value & 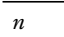 & Mean (SEM) & $p$ Value & $n$ & Mean (SEM) & $p$ Value \\
\hline \multicolumn{10}{|l|}{ Smoking in home: } \\
\hline Yes & 327 & $78.2(1.9)$ & 0.005 & 144 & $23.6(1.1)$ & 0.651 & 429 & $15.8(0.3)$ & 0.010 \\
\hline No & 313 & $70.7(1.9)$ & & 166 & $24.3(1.2)$ & & 476 & $14.7(0.3)$ & \\
\hline \multicolumn{10}{|l|}{ Structure of house: } \\
\hline Wood & 454 & $75.8(1.6)$ & & 156 & $24.1(1.3)$ & & 584 & $14.2(0.3)$ & \\
\hline \multicolumn{10}{|l|}{ Window frames: } \\
\hline Aluminium & 589 & $76.2(1.4)$ & $<0.001$ & 299 & $24.0(0.9)$ & 0.749 & 845 & $15.3(0.2)$ & 0.042 \\
\hline Wood & 51 & $55.9(3.9)$ & & 11 & $22.6(4.5)$ & & 60 & $13.6(0.7)$ & \\
\hline
\end{tabular}


Table 3 Results of multiple regressions of ambient $\mathrm{NO}_{2}$ concentration, smoking at home, structure of the house, and window frames on indoor $\mathrm{NO}_{2}$ concentrations $(p p b)$

\begin{tabular}{|c|c|c|c|c|c|c|c|c|c|c|c|c|}
\hline \multirow[b]{3}{*}{ Variable } & \multicolumn{8}{|c|}{ Heating period } & & & & \\
\hline & \multicolumn{4}{|c|}{ Homes with unvented heaters } & \multicolumn{4}{|c|}{ Homes with vented heaters } & \multicolumn{4}{|c|}{ Non-heating period } \\
\hline & Coef & $S E$ & Std coef & p Value & Coef & $S E$ & Std coef & p Value & Coef & $S E$ & Std coef & $p$ Value \\
\hline \multicolumn{13}{|l|}{ Distance from trunk roads $0-49 \mathrm{~m}$ : } \\
\hline Intercept & 26.664 & & & & -4.688 & & & & 17.283 & & & \\
\hline $\begin{array}{l}\text { Ambient } \mathrm{NO}_{2} \text { concentration } \\
(\mathrm{ppb})\end{array}$ & 1.066 & 0.536 & 0.277 & 0.053 & 0.673 & 0.309 & 0.380 & 0.038 & -0.014 & 0.116 & -0.015 & 0.902 \\
\hline Smoking in home $e^{\star}$ & 12.169 & 8.746 & 0.189 & 0.171 & 3.755 & 5.594 & 0.121 & 0.507 & 0.919 & 1.180 & 0.091 & 0.439 \\
\hline Structure of house $\dagger$ & -15.592 & 9.038 & -0.243 & 0.092 & 9.419 & 6.158 & 0.270 & 0.137 & -1.659 & 1.216 & -0.163 & 0.177 \\
\hline Window frames ${ }^{\ddagger}$ & 12.016 & 31.156 & 0.053 & 0.702 & -1.736 & 16.493 & -0.019 & 0.917 & 2.627 & 5.204 & 0.059 & 0.615 \\
\hline \multicolumn{13}{|l|}{ Others: } \\
\hline Intercept & 51.642 & & & & 17.101 & & & & 9.110 & & & \\
\hline $\begin{array}{l}\text { Ambient } \mathrm{NO}_{2} \text { concentration } \\
(\mathrm{ppb})\end{array}$ & 0.041 & 0.140 & 0.012 & 0.770 & 0.262 & 0.083 & 0.192 & 0.002 & 0.251 & 0.027 & 0.315 & $<0.001$ \\
\hline Smoking in home $e^{\star}$ & 6.573 & 2.747 & 0.097 & 0.017 & -1.296 & 1.740 & -0.044 & 0.457 & 0.990 & 0.407 & 0.078 & 0.015 \\
\hline Structure of house $†$ & -5.931 & 3.148 & -0.078 & 0.060 & -2.548 & 1.802 & -0.087 & 0.158 & 1.756 & 0.461 & 0.131 & $<0.001$ \\
\hline Window frames $\ddagger$ & 21.600 & 5.008 & 0.178 & $<0.001$ & 0.818 & 4.741 & 0.010 & 0.863 & -0.066 & 0.805 & -0.003 & 0.934 \\
\hline
\end{tabular}

Regression analysis was conducted separately for the type of heater, the measurement period, and the distance from trunk roads.

Coef=regression coefficient; $\mathrm{SE}=$ standard error of the regression coefficient; $\mathrm{Std}$ coef=standardised regression coefficient.

$\star$ Yes $=1 ;$ no $=0$.

†Steel or reinforced concrete $=1$, wood $=0$.

$\ddagger$ Aluminium $=1$, wood $=0$.

the roadside area, but the effects of cigarette smoking in the room and the type of window frames were significant in the areas other than the roadside. In homes with vented heaters, atmospheric $\mathrm{NO}_{2}$ concentrations significantly contributed to indoor $\mathrm{NO}_{2}$ in both areas. During the non-heating period, atmospheric $\mathrm{NO}_{2}$ concentrations, cigarette smoking in the room, and the structure of the house were significantly related to indoor $\mathrm{NO}_{2}$ for homes located in areas other than the roadside. Of these, the effect of the atmospheric $\mathrm{NO}_{2}$ concentration was the most significant factor. However, no factor was significant in homes located in the roadside area.

Figure 3 shows the relations between the atmospheric $\mathrm{NO}_{2}$ and the average concentrations of $\mathrm{NO}_{2}$ in each period in the homes of pupils attending each school. During the heating period, the average concentrations in homes with unvented heaters were not related to the atmospheric $\mathrm{NO}_{2}$ in either the roadside area or areas other than the roadside. In homes with vented heaters, however, a significant relation was found between the mean values of indoor
$\mathrm{NO}_{2}$ and the atmospheric concentrations in these two areas. During the non-heating period, the average concentrations of indoor $\mathrm{NO}_{2}$ were significantly related to the atmospheric concentrations in homes located in areas other than the roadside, although no such relation was found for those in the roadside area.

\section{Discussion}

Epidemiological studies have shown that exposure to $\mathrm{NO}_{2}$ increased the prevalence of respiratory symptoms and diseases in children, ${ }^{18} 19$ although the findings have not been entirely consistent. ${ }^{910}$ The atmospheric concentrations of $\mathrm{NO}_{2}$ are higher in areas adjacent to main roads with heavy traffic than in the general environment. $^{23}$ Consequently, there has been concern about the effects of automobile exhaust on the health of people who live near main roads. Recently, several studies have reported a high prevalence of respiratory symptoms in people who lived along main roads. ${ }^{4520}$ This has caused particular concern in Japan, where many homes front on to trunk roads with heavy traffic. ${ }^{2}{ }^{3}$

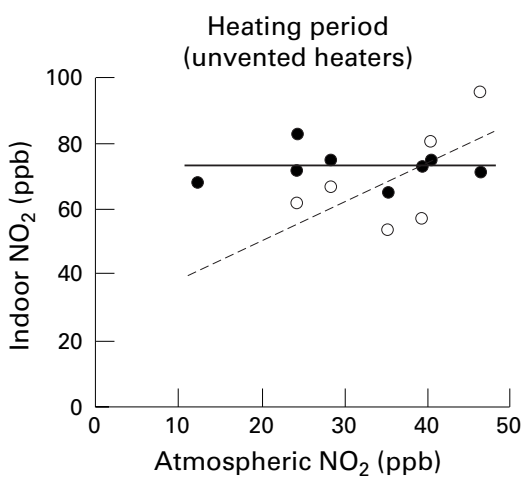

$$
\begin{aligned}
& \text { - } 0-49 m: Y=1.189 X+27.47 \\
&(r=0.610 ; p=0.198) \\
&- \text { Others }: Y=-0.016 X+73.55 \\
&(r=-0.033 ; p=0.932)
\end{aligned}
$$
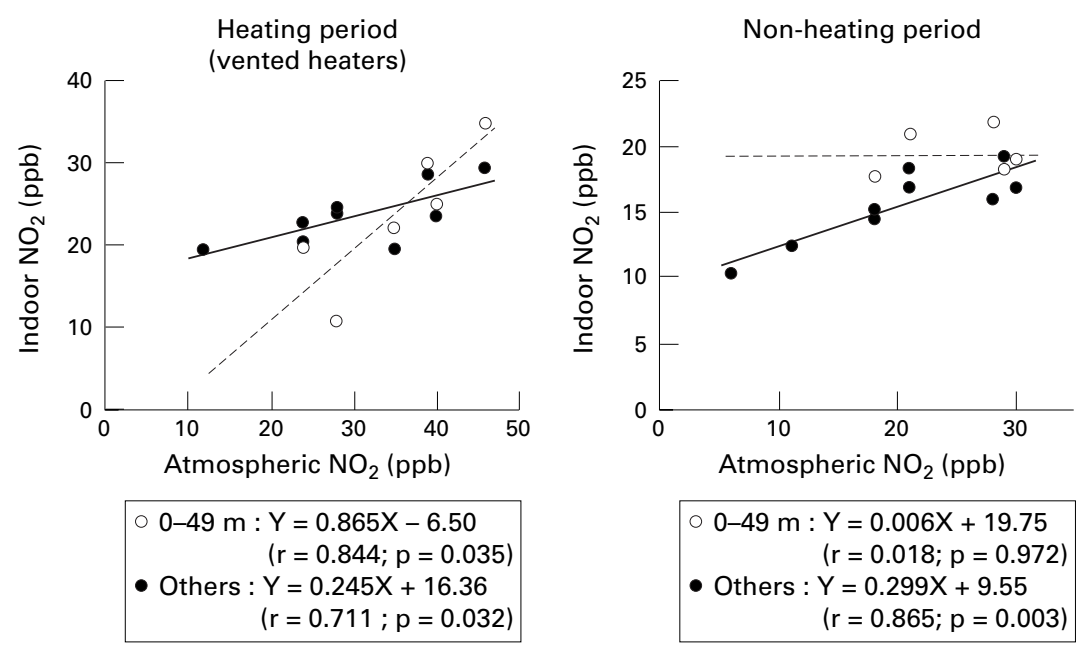

Figure 3 Relations between the mean of indoor $\mathrm{NO}_{2}$ concentrations and atmospheric $\mathrm{NO}_{2}$ concentrations by distance from roads and period. The points on the graphs represent groups of pupils from each school, and the data for pupils attending the urban schools with homes $<50 \mathrm{~m}$ from a trunk road were analysed separately. 
Indoor sources of $\mathrm{NO}_{2}$ that cause indoor air pollution are regarded as environmental factors. ${ }^{7821}$ To evaluate the potential health effects of outdoor and indoor $\mathrm{NO}_{2}$, direct measurement of personal exposure concentrations is considered desirable. ${ }^{22}$ Passive diffusion monitors for $\mathrm{NO}_{2}$ have been used in epidemiological studies, but few of these studies have dealt with many subjects. ${ }^{18}$ In large scale epidemiological investigations, measurements of indoor $\mathrm{NO}_{2}$ concentrations, which are assumed to contribute greatly to personal exposure, ${ }^{23} 24$ have often been carried out as an alternative..$^{25} 26$

Numerous investigations have shown that indoor $\mathrm{NO}_{2}$ concentrations may be high in homes with unvented combustion appliances, particularly gas or kerosene heaters. ${ }^{7-9} 25$ The present study also showed that indoor $\mathrm{NO}_{2}$ concentrations during the heating period were extremely high in homes with unvented heaters. We had previously reported that indoor $\mathrm{NO}_{2}$ concentrations were found to be more than 100 $\mathrm{ppb}$ in some homes even with vented heaters, and indicated that surveys that used questionnaires could lead to misclassification of the type of heating appliance. ${ }^{16}$ In the present study, the use and type of heating appliance were ascertained by the same questionnaires used in previous surveys. ${ }^{16}$ Also, the presence or absence of an exhaust outlet was confirmed by illustrations of various outlets. The indoor $\mathrm{NO}_{2}$ concentrations were $<80 \mathrm{ppb}$ in the homes that reported using vented heaters, with the exception of only one home, and both the mean value and range were smaller than those reported in the previous study. It seems that confirming the presence or absence of an exhaust outlet with illustrations is a more appropriate method than simply inquiring into the type of heating appliances used. In homes with unvented heaters, the variation in indoor $\mathrm{NO}_{2}$ concentrations was notably high. This may be due to the hours of use of heating appliances and the distance between the heaters and the $\mathrm{NO}_{2}$ samplers. Additional consideration about the use of heaters is needed to evaluate the variation in indoor $\mathrm{NO}_{2}$ during the heating period.

The effects of the airtightness of dwellings on indoor $\mathrm{NO}_{2}$ concentrations were evaluated. During the non-heating period, the indoor $\mathrm{NO}_{2}$ concentrations were significantly higher in steel or reinforced concrete houses than in wooden houses. During the heating period, however, no difference was found relative to the structure of the house. Nakai et $a l^{\beta}$ found no consistent association between the structure of the house and indoor $\mathrm{NO}_{2}$ concentrations, although they showed that the concentrations differed by the types of house structure. The relation between structure of the house and indoor $\mathrm{NO}_{2}$ should be further evaluated.

In homes with unvented heaters during the heating period, the indoor $\mathrm{NO}_{2}$ concentrations were higher in homes with aluminium window frames than in those with wooden window frames. In homes with vented heaters, however, there were no differences relative to type of window frames, which were similar results to those obtained by Nakai et $a l^{\beta}$ and Ono et al. ${ }^{27}$
Multiple regression analysis showed that aluminium window frames were significantly associated with higher indoor $\mathrm{NO}_{2}$ concentrations only in homes with unvented heaters during the heating period. The airtightness of houses with aluminium window frames seems to increase indoor $\mathrm{NO}_{2}$ concentrations in the presence of indoor sources - such as unvented heating appliances.

The use of gas cooking stoves and pilot lights has also been known to increase indoor $\mathrm{NO}_{2}$ concentrations, particularly in the kitchen. ${ }^{21} 2829$ Although almost all homes in Japan use gas appliances for cooking, gas stoves with pilot lights are rarely used. ${ }^{27}$ Therefore, although ventilation rates, size, and layout of dwellings should be considered, ${ }^{30}$ we did not obtain detailed information on these factors. Further study will be needed to determine the effects of gas cooking appliances in Japanese homes.

There have been numerous reports on the effects of cigarette smoking on $\mathrm{NO}_{2}$ concentrations. Koo et $a l^{30}$ and Adgate et $a l^{1}$ found no relation between the intensity of smoking and personal exposures to $\mathrm{NO}_{2}$. In contrast, Leaderer $e t a l^{8}$ and Goldstein $e t a l^{8}$ reported that the presence of smokers in the household increased indoor $\mathrm{NO}_{2}$. Klus et $a l^{32}$ found that the nitric oxide (NO) concentration increased in a room during smoking without an increase in $\mathrm{NO}_{2}$ concentrations, and that the concentration of $\mathrm{NO}_{2}$ rose once the smoking had stopped. In the present study, cigarette smoking in indoor environments was associated with higher concentrations of $\mathrm{NO}_{2}$ in homes with unvented heaters during the heating period, and the relation was also significant during the non-heating period. Also, multiple regression analysis showed that cigarette smoking increased indoor $\mathrm{NO}_{2}$ concentrations in the homes located in areas other than the roadside.

It has been shown that the atmospheric $\mathrm{NO}_{2}$ concentrations were highest at the edge of trunk roads and decreased with the distance from the roadside. ${ }^{2}{ }^{3}$ Although such variations in $\mathrm{NO}_{2}$ concentrations depend on the road structure, adjacent buildings, and atmospheric conditions, ${ }^{33}$ the concentrations have been known to decrease gradually up to a distance of $50 \mathrm{~m}$ from the roadside, and not to vary further away. ${ }^{2}$ Nakai et $a l^{\beta}$ and Ono et $a l^{27}$ reported that indoor $\mathrm{NO}_{2}$ concentrations were higher in homes $<20 \mathrm{~m}$ from the roadside than in those further away. In the present study, the homes $<50 \mathrm{~m}$ from the edge of roads were classified as roadside homes when considering the number of subjects and the variations in $\mathrm{NO}_{2}$ concentrations relative to distance from the roads. Consequently, indoor $\mathrm{NO}_{2}$ concentrations for each area during the non-heating period decreased according to the following factors: roadside, non-roadside, suburban, and rural areas, which corresponded to the respective atmospheric $\mathrm{NO}_{2}$ concentrations in the areas.

Rutishauser $e t a l^{34}$ found a high correlation between indoor and outdoor $\mathrm{NO}_{2}$ concentrations. Dockery et $a l^{\beta 5}$ and Sexton et $a l^{\beta 6}$ showed that indoor $\mathrm{NO}_{2}$ concentrations could be estimated from the outdoor $\mathrm{NO}_{2}$ concentrations and type of gas cooking stoves. In the 
areas other than the roadside, the relation between atmospheric $\mathrm{NO}_{2}$ and concentrations of indoor $\mathrm{NO}_{2}$ in the homes of pupils attending each school was significant for those homes in which vented heaters were used during the heating period: the relation was also shown during the non-heating period. In roadside areas, this relation was significant only in homes in which vented heaters were used during the heating period, but it was not apparent during the non-heating period.

Multiple regression analysis also showed that the proportions of variation in indoor $\mathrm{NO}_{2}$ that are explained by atmospheric $\mathrm{NO}_{2}$ concentration differed relative to the type of heater, the period, and the distance from trunk roads. These results suggested that the atmospheric air pollution due to automobile exhaust also contributed to the variation in indoor $\mathrm{NO}_{2}$ in the roadside areas. In homes with unvented heaters during the heating period, there was no relation between indoor and atmospheric $\mathrm{NO}_{2}$ concentrations in either area. This is probably because the variation due to the use of unvented heaters was so great as not to distinguish the effect of the atmospheric air pollution.

The presence of other pollutants - such as particulate matter and formaldehyde-in the indoor environment should be also considered to contribute to human health, but simple monitors suited for epidemiological studies are unavailable for pollutants other than $\mathrm{NO}_{2}$.

In conclusion, this study showed that indoor $\mathrm{NO}_{2}$ concentrations were affected considerably by the use of unvented heaters during the heating period, and that the mean values of indoor $\mathrm{NO}_{2}$ in the homes of pupils attending each school were related to atmospheric $\mathrm{NO}_{2}$ concentrations. Multiple regression analysis also showed that the indoor $\mathrm{NO}_{2}$ concentrations were associated with atmospheric concentrations in homes with vented heaters during the heating period, and similarly during the nonheating period. Indoor $\mathrm{NO}_{2}$ concentrations were higher in homes in roadside areas than in the other areas, during the non-heating period. These findings suggested that indoor $\mathrm{NO}_{2}$ concentrations reflect the effect of automobile exhaust. However, the relation between indoor and outdoor $\mathrm{NO}_{2}$ concentrations was not clear in homes in roadside areas. In this study, each measurement was carried out on only one day during both the heating and non-heating periods. Also, only six schools formed the subject of roadside areas. The relation between indoor and outdoor $\mathrm{NO}_{2}$ concentrations in roadside areas should be further evaluated.

1 Japan Environment Agency. White Paper on the Environment. $A$ volume of details. Tokyo: Printing Bureau, Ministry of Finance, 1996:24-49. (In Japanese.)

2 Nitta H, Sato T, Nakai S, et al. Respiratory health associated witta $\mathrm{H}$, Sato T, Nakai S, et al. Respiratory health associated
with exposure to automobile exhaust. I. Results of cross with exposure to automobile exhaust. I. Results of cross Health 1993;48:53-8.

3 Nakai S, Nitta H, Maeda K. Respiratory health associated with exposure to automobile exhaust: II. Personal $\mathrm{NO}$ exposure levels according to distance from the roadside. $\mathscr{f}$ Expo Anal Environ Epidemiol 1995;5:125-36.

4 Oosterlee A, Drijver M, Lebret E, et al. Chronic respiratory symptoms in children and adults living along streets with high traffic density. Occup Environ Med 1996;53:241-7.

5 Wjst $M$, Reitmeir P, Dold $S$, et al. Road traffic and adverse $596-600$
6 Edwards J, Walters S, Griffiths RK. Hospital admissions for asthma in preschool children: relationship to major roads in Birmingham, United Kingdom. Arch Environ Health 1994; 49:223-7.

7 Samet JM, Marbury MC, Spengler JD. Health effects and sources of indoor air pollution. Part I. Am Rev Respir Dis 1987;136:1486-508

8 Leaderer BP, Zagraniski RT, Berwick M, et al. Assessment of exposure to indoor air contaminants from combustion sources: methodology and application. Am $\mathcal{f}$ Epidemiol 1986;124:275-89.

9 Dijkstra L, Houthuijs D, Brunekreef B, et al. Respiratory health effects of the indoor environment in a population of Dutch children. Am Rev Respir Dis 1990;142:1172-8.

10 Brunekreef B, Houthuijs D, Dijkstra L, et al. Indoor nitrogen dioxide and children's pulmonary function. F Air Waste Manage Assoc 1990;40:1252-6.

11 Samet JM, Lambert WE, Skipper BJ, et al. A study of respiratory illnesses in infants and nitrogen dioxide exposure. Arch Environ Health 1992;47:57-63.

12 Shima $M$, Adachi $M$. Serum immunoglobulin $E$ and hyaluronate levels in children living along major roads. Arch Environ Health 1996;51:425-30.

13 Shima M, Adachi M. Association of respiratory symptoms with serum protease inhibitors and albumin levels in Japanese children. Int F Epidemiol 1996;25:1213-9.

14 Saltzman BE. Colorimetric microdetermination of nitrogen dioxide in the atmosphere. Anal Chem 1954;26:1949-55.

15 Yanagisawa Y, Nishimura H. A badge-type personal sampler for measurement of personal exposure to $\mathrm{NO}_{2}$ and $\mathrm{NO}$ in ambient air. Environ Int 1982;8:235-42.

16 Shima M, Nitta Y, Adachi M. Indoor nitrogen dioxide concentrations in homes along major arterial roads and their affecting factors. Fournal of Fapan Society of Air Pollution 1994;29:123-32. (In Japanese with English abstract.)

17 Ferris BG. Epidemiology standardization project. II. Recommended respiratory disease questionnaires for use with adults and children in epidemiological research. Am Rev Respir Dis 1978;118(suppl 6):7-53.

18 Pershagen G, Rylander E, Norberg S, et al. Air pollution involving nitrogen dioxide exposure and wheezing bronchitis in children. Int f Epidemiol 1995;24:1147-53.

19 Braun-Fahrländer C, Ackermann-Liebrich U, Schwartz J, et Braun-Fahrländer C, Ackermann-Liebrich $\mathrm{U}$, Schwartz J, et
al. Air pollution and respiratory symptoms in preschool al. Air pollution and respiratory symptoms
children. Am Rev Respir Dis 1992;145:42-7.

20 Weiland SK, Mundt KA, Rückmann A, et al. Self-reported wheezing and allergic rhinitis in children and traffic density on street of residence. Ann Epidemiol 1994;4:243-7.

21 Jarvis D, Chinn S, Luczynska C, et al. Association of respiratory symptoms and lung function in young adults with use of domestic gas appliances. Lancet 1996;347:426-31.

22 Linaker $\mathrm{CH}$, Chauhan AJ, Inskip $\mathrm{H}$, et al. Distribution and determinants of personal exposure to nitrogen dioxide in school children. Occup Environ Med 1996;53:200-3.

23 Hoek G, Meijer R, Scholten A, et al. The relationship between indoor nitrogen dioxide concentration levels and personal exposure: a pilot study. Int Arch Occup Environ Health 1984;55:73-8.

24 Noy D, Lebret E, Willers H, et al. Estimating human exposure to nitrogen dioxide: results from a personal monitoring study among housewives. Environment International 1986;12:407-11.

25 Neas LM, Dockery DW, Ware JH, et al. Association of indoor nitrogen dioxide with respiratory symptoms and pulmonary function in children. Am $\mathcal{F}$ Epidemiol 1991;134: 204-19.

26 Remijn B, Fischer P, Brunekreef B, et al. Indoor air pollution and its effect on pulmonary function of adult non-smoking women. I. Exposure estimates for nitrogen dioxide

27 Ono M, Hirano S, Murakami M, et al. Measurements of particle and $\mathrm{NO}_{2}$ concentrations in homes along the major arterial roads in Tokyo. Fournal of fapan Society of Air Pollution 1989;24:90-9. (In Japanese with English abstract.)

28 Goldstein BD, Melia RJW, Chinn S, et al. The relation between respiratory illness in primary schoolchildren and
the use of gas for cooking. II. Factors affecting nitrogen dioxide levels in the home. Int f Epidemiol 1979;8:339-45.

29 Marbury MC, Harlos DP, Samet JM, et al. Indoor residential $\mathrm{NO}_{2}$ concentrations in Albuquerque, New Mexico. $\mathcal{F}$ Air Pollut Control Assoc 1988;38:392-8.

30 Koo LC, Ho JH-C, Ho C-Y, et al. Personal exposure to nitrogen dioxide and its association with respiratory illness in Hong Kong. Am Rev Respir Dis 1990;141:1119-26.

31 Adgate JL, Reid HF, Morris R, et al. Nitrogen dioxide exposure and urinary excretion of hydroxyproline and desmosine. Arch Environ Health 1992;47:376-84.

32 Klus $\mathrm{H}$, Begutter $\mathrm{H}$, Nowak A, et al. Indoor air pollution due to tobacco smoke under real conditions. Preliminary results. Tokai f Exp Clin Med 1985;10:331-40.

33 Matsumoto Y, Shindo J, Tamura K, et al. Spatio-temporal variations of daily average concentration of $\mathrm{NO}_{2}$ in an area variations of daily average concentration of $\mathrm{NO}_{2}$ in an area
with trunk roads. fournal of fapan Society of Air Pollution 1994;29:41-54. (In Japanese with English abstract.)

34 Rutishauser M, Ackermann U, Braun Ch, et al. Significant association between outdoor $\mathrm{NO}_{2}$ and respiratory symptoms in preschool children. Lung 1990;168(suppl):347-52.

35 Dockery DW, Spengler JD, Reed MP, et al. Relationships among personal, indoor and outdoor $\mathrm{NO}_{2}$ measurements. Environment International 1981;5:101-7.

36 Sexton K, Letz R, Spengler JD. Estimating human exposure to nitrogen dioxide: an indoor/outdoor modeling approach. Environ Res 1983;32:151-66. 